\title{
Model Analysis of Student Satisfaction Based on Campus Image and Quality of Service
}

\author{
Rini Nurahaju* Nurul Sih Widanti \\ Psychology Faculty, Hang Tuah University, Surabaya, Indonesia
}

\begin{abstract}
The type of research used is explanatory research, which aims to explain the influence between variables through hypothesis testing. The latent variables used in this study are exogenous variables, namely Higher Education Image (CPT) and Service Quality (KLY). While the endogenous variable is Consumer Satisfaction (KEP). Data collection techniques using a Likert scale, namely the image scale contains 18 items which include 6 items on 3 indicators, the service quality scale contains 18 items which include 6 items on 3 indicators and the consumer satisfaction scale contains 30 items which include 6 items on 5 indicators. These items include favorable and unfavorable. The implementation of this research in June to July 2021 on 435 students which includes representatives of active male and female students at University X. The scale is distributed using Google Forms. The data analysis technique uses SEM because of its ability to present a comprehensive model, confirm the dimensions and a construct/factor and measure the effects and relationships theoretically. The software program used is PLS-Smart. The results of the study resulted in the following findings. First, there is the effect of Campus Image and Service Quality on Consumer Satisfaction of 0.780 . Second, the image of Campus has a significant effect on consumer satisfaction of 0.246 . Third, service quality has a significant effect on consumer satisfaction of 0.679 .
\end{abstract}

Keywords: Higher Education Image, Service Quality, Consumer Satisfaction

DOI: $10.7176 / \mathrm{JEP} / 12-34-01$

Publication date: December $31^{\text {st }} 2021$

\section{Introduction}

The higher education service industry is currently facing a condition of intense competition. Prospective students get many options to continue their studies. The increasing number of universities, both private and public, is certainly a challenge for each university to be able to attract as many students as possible. It can be seen from the decreasing number of students enrolling in several universities. This condition also happened at one of the private campuses in Surabaya.

Table 1.

Number of Students for Academic Year 2014-2015 until 2019-2020 of University "X" Surabaya

\begin{tabular}{|l|l|c|}
\hline No & Academic Year & Number of Students \\
\hline 1 & $2014-2015$ & 1114 \\
\hline 2 & $2015-2016$ & 1392 \\
\hline 3 & $2016-2017$ & 1337 \\
\hline 4 & $2017-2018$ & 1576 \\
\hline 5 & $2018-2019$ & 1289 \\
\hline 6 & $2019-2020$ & 1143 \\
\hline
\end{tabular}

Source: University "X” Work Program Report

Table 1. shows that University " $X$ " in 2017-2018 had accepted 1576 students (the highest number), but in the following years it decreased.

Many factors have contributed to the declining interest of a university, such as the university's low ability to satisfy its customers. Customers, namely students, are a very valuable asset in industrial development, including in the higher education service industry.

According to Lupiyoadi and Hamdani (2008), there are several things that need to be considered in a study of the characteristics of services at higher education institutions, namely: 1. Universities are a group of pure services (pure service), where the service provided is supported by work tools. or mere supporting facilities, such as classrooms, chairs, tables, and books; 2 . The services provided require the presence of service users (students), so customers come to the educational institution to get the desired service (although in its development there are those who offer open university programs and distance lectures and so on); 3 . The service recipient is a person, so based on the relationship with service users (customers / students) it is a high contact system, namely the relationship between service providers and customers is high. Customers and service providers continue to interact throughout the service delivery process. To receive services, customers must be part of the service system; 4 . The relationship with the customer is based on a member relationship, where the customer has become a member of the educational institution, the service delivery system is continuous and regular according to the established curriculum. 
In the context of this study, student satisfaction was analyzed based on the Servqual model. According to Parasuraman, Zeithaml and Berry in Tjiptono and Chandra (2016) the dimensions and attributes of the Servqual model consist of Tangible, Empathy, Responsiveness, Reliability, and Assurance. While associated with education, Tangible (Physical Evidence), is a form of physical manifestation which is conducted by lecturers and administrative staffs who show their performance in helping students so that they feel satisfied with the services received. Empathy is giving attention, seriousness, sympathy, and understanding to the problems experienced by students according to their level of understanding, understanding, and needs. Responsiveness, is the ability of lecturers and administrative staffs to provide services responsively to students according to the level of absorption, understanding, of various things related to the form of service that they do not know, so that the service gets a positive response. Reliability is the ability of lecturers and administrative staffs who have high knowledge, expertise, and work professionalism in providing services immediately, quickly, and smoothly so as to produce satisfactory forms of service, without any complaints and excessive impressions of the services that have been provided given. Assurance, namely the behavior of lecturers and administrative staffs who are able to foster student confidence about their university and the university can provide a sense of safety.

Then what affects customer satisfaction? According to Zeithmal and Bitner as quoted by Adam (2015) revealed that company image can affect satisfaction. Meanwhile, Lupiyoadi (2006) argued that those which affect customer satisfaction include service quality.

From this explanation, what needs attention in the context of this research is the image and quality of the university services. Why should it be the image of the College? Because the proliferation of universities that offer good quality services is a challenge for each university. To win the competition, the University needs to offer an attraction to raise the image of the university. A good image will lead to a positive response from the community towards the university. This will increase the possibility of the community to make a decision to choose a university that is considered good, which in turn will have a positive impact on the university. The image of a university is formed from image, impressions, and feelings based on experiences about the quality of service experienced by a person towards the university (Panjaitan, 2011). Consumers buy something not just because they need the item, but there is something else they expect. Something else is in accordance with the image formed in them. Therefore, it is very important for organizations to provide information to the public in order to form a good image (Panjaitan, 2011). In the context of higher education, the image of the university can be defined as the sum of all the beliefs that individuals have towards the university (Landrum et al (1998) and Arpan et al (2003) in Helena Alves and Ma'rio Raposo, 2010 in Dirgantari, 2012). According to Panjaitan (2011) University image is measured using three dimensions, namely academic reputation, future career, and campus appearance.

Related research has been conducted by Cid, Renata and Alexander, 2004 (in Panjaitan, 2011). One of the results in the study showed that that the image has a direct effect on consumer satisfaction. The results of research by Arwanda et.al (2014) and Setiyawan (2016) showed that the image of the university has an effect on student satisfaction. Likewise, Dib's (2013) research resulted in one finding that image has a direct influence on consumer (student) satisfaction at Syrian Universities. Likewise, the results of university image research have a positive influence on student satisfaction of IKIP PGRI Bojonegoro (Mujahidin, 2018). Therefore, the hypothesis 1 that is built is that the image of the university has a significant effect on student satisfaction.

In addition to the image of the university, the quality of service provided by the campus, in this case the university and faculties, is equally important to be able to shape student satisfaction. In the service industry, the measured product quality is service quality. The management must understand the overall service offered from the customer's point of view. Service quality that is formed from the customer's point of view can provide more value to the products offered. The company must realize the quality in accordance with the requirements demanded by the customer. In other words, quality is a consistently and efficient way to give customers what they want. According to Parasuraman (in Panjaitan, 2011) service quality is based on a comparison between what should be offered and what is provided. According to Zeithaml et al (1998) service quality is described as a form of attitude, related to satisfaction obtained by comparing expectations with performance. The main thing that underlies a service quality is its dimensions that can be used to evaluate service quality regardless of the type of service. Factors that related to student satisfaction with the services provided by educational institutions are 1) Human Resources. 2) Curriculum 3) Facilities and Infrastructure.

The relationship between service quality and customer satisfaction is quite close. According to the results of previous research by Rustami et al (2000) showed that student satisfaction is influenced by the quality of educational services in the amount of $52.5 \%$ while the remaining of $47.5 \%$ is influenced by other variables. Jeanne Ananti Susanto, 2004 (in Panjaitan, 2011) examined the effect of service quality significantly on the satisfaction and loyalty of 140 condominium consumers in Surabaya. Likewise research conducted by Reina (2012), the results showed that service quality had a significant effect on student satisfaction. Therefore, hypothesis 2 that is built is that service quality has a significant effect on customer satisfaction.

Thus, related to the theory and the results of previous studies, the image of the university owned by University " $\mathrm{X}$ " and the quality of educational services are very important to shape student satisfaction as consumers. 
Therefore Hypothesis 3 is a model of consumer satisfaction can be built by the image of the college and service quality.

\section{Method Research}

The type of research used is explanatory research, which aims to explain the influence between variables through hypothesis testing. The hypothesis in the form of model is based on theoretical studies and empirical research. The latent variables used in this study are exogenous variables, namely Higher Education Image (CPT) and Service Quality (KLY). While the endogenous variable is Consumer Satisfaction (KEP).

The variable of Higher Education Image is measured using a scale that is based on indicators 1. Academic reputation (CPT 1) 2. Future career (CPT 2) 3. Campus appearance (CPT 3). The indicators above are used to determine student perceptions of the university's image. If the subject gets a high value or score, it shows that the subject tends to have a positive perception on the image of the university and vice versa if the subject gets a low score or score, it indicates that the subject tends to have a negative perception on the image of the university.

The service quality variable is measured using a scale based on indicators 1. Human resources (KLY 1) 2. Curriculum (KLY 2) 3. Infrastructure (KLY 3). The indicators above are used to determine student perceptions of service quality. If the subject gets a high value or score, it indicates that the subject tends to have a positive perception of service quality and vice versa if the subject gets a low score or score, it indicates that the subject tends to have a negative perception of service quality.

Student satisfaction variable is measured using a scale based on indicators 1. Reliability (KEP 1), 2. Responsiveness (KEP 2) 3. Assurance (KEP 3) 4. Empathy (KEP 4) 5. Tangibles (KEP 5). If the subject gets a high score or score, it indicates that the subject tends to have high satisfaction and vice versa if the subject gets a low score or score, it indicates that the subject tends to have low satisfaction.

Data collection techniques using a Likert scale, namely the image scale contains 18 items which include 6 items on 3 indicators, the service quality scale contains 18 items which include 6 items on 3 indicators and the consumer satisfaction scale contains 30 items which include 6 items on 5 indicators. These items include favorable and unfavorable.

From each item there are five answer choices, namely from Strongly Agree (score 5) to Strongly Disagree (score 1) for the favorite item and vice versa, Strongly Agree (score 1) to Strongly Disagree (score 5) on the unfavorable item.

The implementation of this research in June to July 2021 on 435 students which includes representatives of active male and female students at University X. The scale is distributed using Google Forms.

The data analysis technique uses SEM because of its ability to present a comprehensive model, confirm the dimensions and a construct/factor and measure the effects and relationships theoretically. The software program used is PLS-Smart.

\section{Result and discussion}

Data analysis was carried out with the following 4 things, namely the description of the research subjects, testing the validity and reliability of measuring instruments, testing the structural equations of consumer satisfaction, and testing hypotheses.

\subsection{Description of research subjects}

Table 2: Description of Research Subjects

\begin{tabular}{|c|c|c|c|c|}
\hline \multicolumn{2}{|c|}{ Description } & Amount & Percentage & Total \\
\hline \multirow[t]{7}{*}{ Faculty } & Cruise Diploma Program & 81 & 18,7 & \multirow[t]{7}{*}{$434(100 \%)$} \\
\hline & Faculty Of Engineering And Marine Science & 57 & 13,1 & \\
\hline & Faculty of Medicine & 30 & 6,9 & \\
\hline & Faculty of Social and Political Science & 38 & 8,8 & \\
\hline & Faculty of Law & 130 & 30,0 & \\
\hline & Faculty of Dentistry & 45 & 10,4 & \\
\hline & Faculty of Psychology & 53 & 12,2 & \\
\hline \multirow{5}{*}{$\begin{array}{l}\text { Class } \\
\text { Year }\end{array}$} & 2020 & 185 & 42,6 & \multirow[t]{5}{*}{$434(100 \%)$} \\
\hline & 2019 & 128 & 29,5 & \\
\hline & 2018 & 76 & 17,5 & \\
\hline & 2017 & 40 & 9,2 & \\
\hline & 2016 & 5 & 1,2 & \\
\hline \multirow[t]{2}{*}{ Gender } & Male & 199 & 45,9 & \multirow[t]{2}{*}{$434(100 \%)$} \\
\hline & Female & 235 & 54,1 & \\
\hline
\end{tabular}

Source: Results of questionnaire data collection, processed. 
From table 2, it can be seen that most of the research subjects are from FH. When viewed from the generation, it is dominated by the class of 2020. Female students are classified as active to participate in this research.

\subsection{Test the validity and reliability of measuring instruments}

Testing the validity of the measuring instrument is carried out with a convergent validity test. The results showed that all latent variable indicators had an AVE (Average Variance Extracted) value greater than 0.5.

Table 3: Validity Test Results

\begin{tabular}{|l|l|l|l|}
\hline No & Variable & Indicator & AVE \\
\hline \multirow{4}{*}{1} & Consumer Satisfaction & Reliability (KEP1), & 0,816 \\
\cline { 3 - 4 } & & Responsiveness (KEP2) & 0,826 \\
\cline { 3 - 4 } & & Assurance (KEP3) & 0,748 \\
\cline { 3 - 4 } & & Empathy (KEP4) & 0,646 \\
\cline { 3 - 4 } & & Tangibles (KEP5). & 0,778 \\
\hline \multirow{2}{*}{2} & College Image & Academic reputation (CPT 1) & 0,827 \\
\cline { 3 - 4 } & & Future career (CPT 2) & 0,818 \\
\cline { 3 - 4 } & & Campus appearance (CPT 3). & 0,802 \\
\hline 3 & \multirow{2}{*}{ Service Quality } & Human Resources (KLY1) & 0,817 \\
\cline { 3 - 4 } & & Curriculum (KLY2) & 0,806 \\
\cline { 3 - 4 } & & Infrastructure (KLY3) & 0,747 \\
\hline
\end{tabular}

Source: Results of questionnaire data collection, processed.

This shows that the measuring instrument is proven to be valid. While the reliability test is done by looking at the composite reliability value. It is said to have good reliability if it is above 0.7 . The test results of this measuring instrument show that almost all values are above 0.7

Table 4: Reliability Test Results

\begin{tabular}{|l|l|l|}
\hline No & Simbul & Composite reliability \\
\hline 1 & CPT 1 & 0.827 \\
\hline 2 & CPT 2 & 0.818 \\
\hline 3 & CPT 3 & 0.802 \\
\hline 4 & KLY 1 & 0.817 \\
\hline 5 & KLY 2 & 0.806 \\
\hline 6 & KLY 3 & 0.747 \\
\hline 7 & KEP 1 & 0.816 \\
\hline 8 & KEP 2 & 0.824 \\
\hline 9 & KEP 3 & 0.748 \\
\hline 10 & KEP 4 & 0.646 \\
\hline 11 & KEP 5 & 0.778 \\
\hline
\end{tabular}

3.3 Testing the structural equation of customer satisfaction

After testing the validity and reliability on all latent variables that have valid and reliable results, then the latent variables can be continued in the analysis in the form of the path diagram presented in Figure 1 below: 


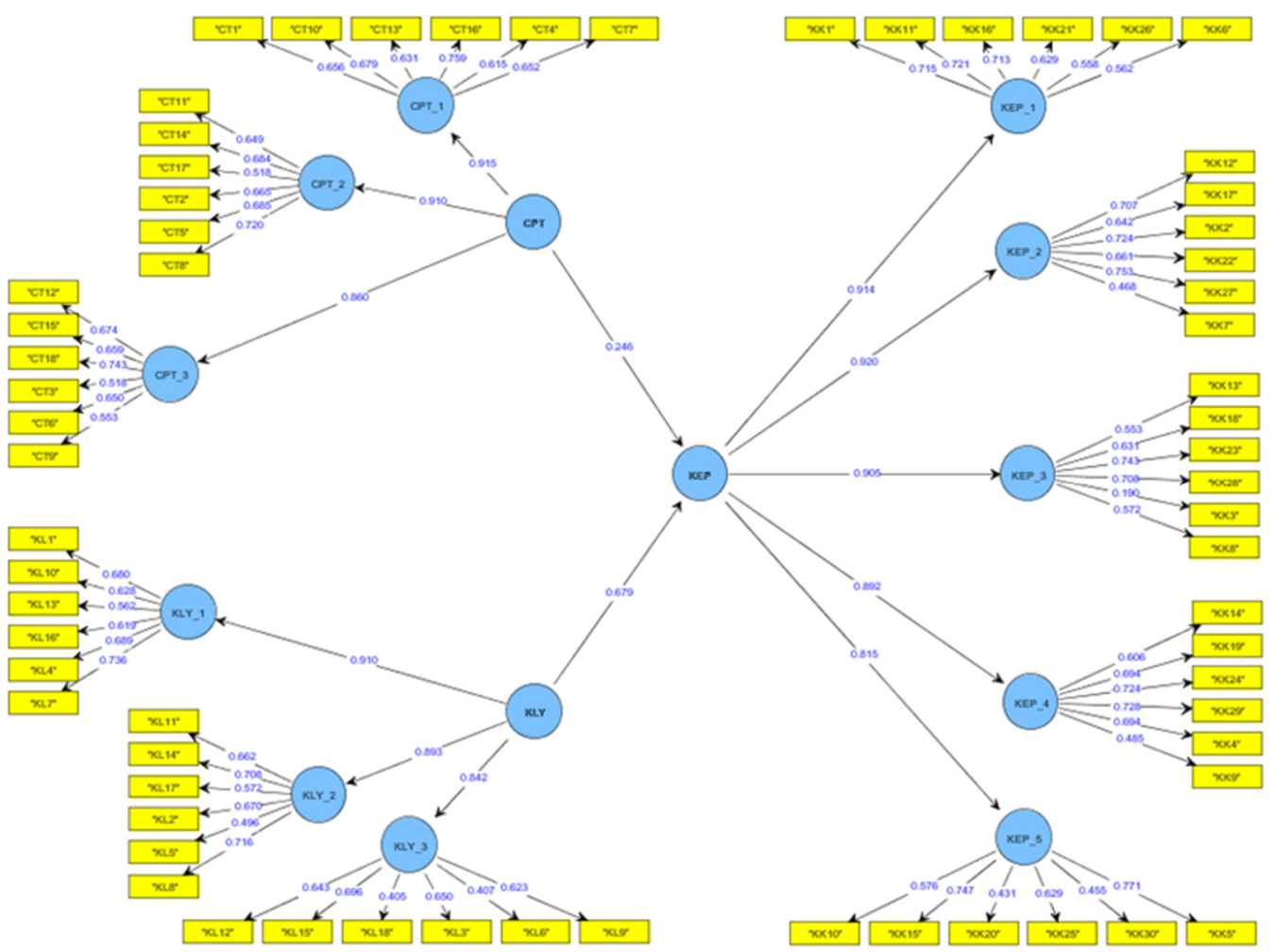

Figure 1

Higher Education Image Model (CPT), Service Quality (KLY) on Student Satisfaction (KEP)

The results of testing the complete model above with the SmartPLS program can be seen from the R-Square value which describes the goodness-of-fit of a model. The recommended R-square value is greater than zero. The results of processing research data using SmartPLS provide an R-square value as shown in Table 5.

Tabel 5. Goodness of Fit dari R-Square

\begin{tabular}{|l|l|}
\hline Variable & $R$-Square \\
\hline College Image, Service Quality $\rightarrow$ Consumer Satisfaction & 0,780 \\
\hline
\end{tabular}

Source: Results of questionnaire data collection, processed.

Table 5 explains that the contribution or proportion of the variable of Higher Education Image, Service Quality to Consumer Satisfaction is 0.780 .

From the appropriate model, it can be interpreted each path coefficient. The path coefficients are hypotheses in this study which can be presented in the following structural equation:

$$
\mathrm{KEP}=0.246 \mathrm{CPT}+0.679 \mathrm{KLY}
$$

\subsection{Hypothesis testing}

Related to the results of hypothesis testing, it shows that the results of the structural path coefficient (inner weight) along with the significance value are as follows

Table 6. Inner Weight Test on Consumer Satisfaction with Bootstrap Sample

\begin{tabular}{|l|l|l|l|}
\hline Influence & \multirow{2}{*}{ Koef. Orginal } & \multicolumn{2}{|l|}{ (Bootstrap, B=100) } \\
\cline { 3 - 4 } & & Koef. & $\mid$ Thit \\
\hline College Image $\rightarrow$ Consumer Satisfaction & 0.246 & 0.240 & 1.993 \\
\hline Service Quality $\rightarrow$ Customer Satisfaction & 0.679 & 0.682 & 6.298 \\
\hline
\end{tabular}

Based on Table 6, the coefficient with bootstrap 50 for each variable is close to the original coefficient, so that the t-statistic data on bootstrap 50 is considered stable and can be used for hypothesis testing. From table 6, the interpretation of each path coefficient is as follows:

Hypothesis 1: Higher Education Image has an effect on Consumer Satisfaction.

The results of the analysis in Table 6 can be seen that the results of the hypothesis test show a positive path coefficient of 0.246 with a $t$-statistic of 1.993 which is greater than $t$ table $=1.96$. This shows that the image of the university has a significant effect on consumer satisfaction.

Hypothesis 2: Service Quality has an effect on Consumer Satisfaction.

The results of the analysis in Table 6 can be seen that the results of the hypothesis test show a positive path coefficient of 0.679 with a t-statistic of 6.298 greater than $t$ table $=1.96$. This shows that service quality has a 
significant effect on customer satisfaction of 0.679 .

Based on the results of testing the hypothesis above, it can be described the influence of the relationship between research variables as shown in Figure 2 below

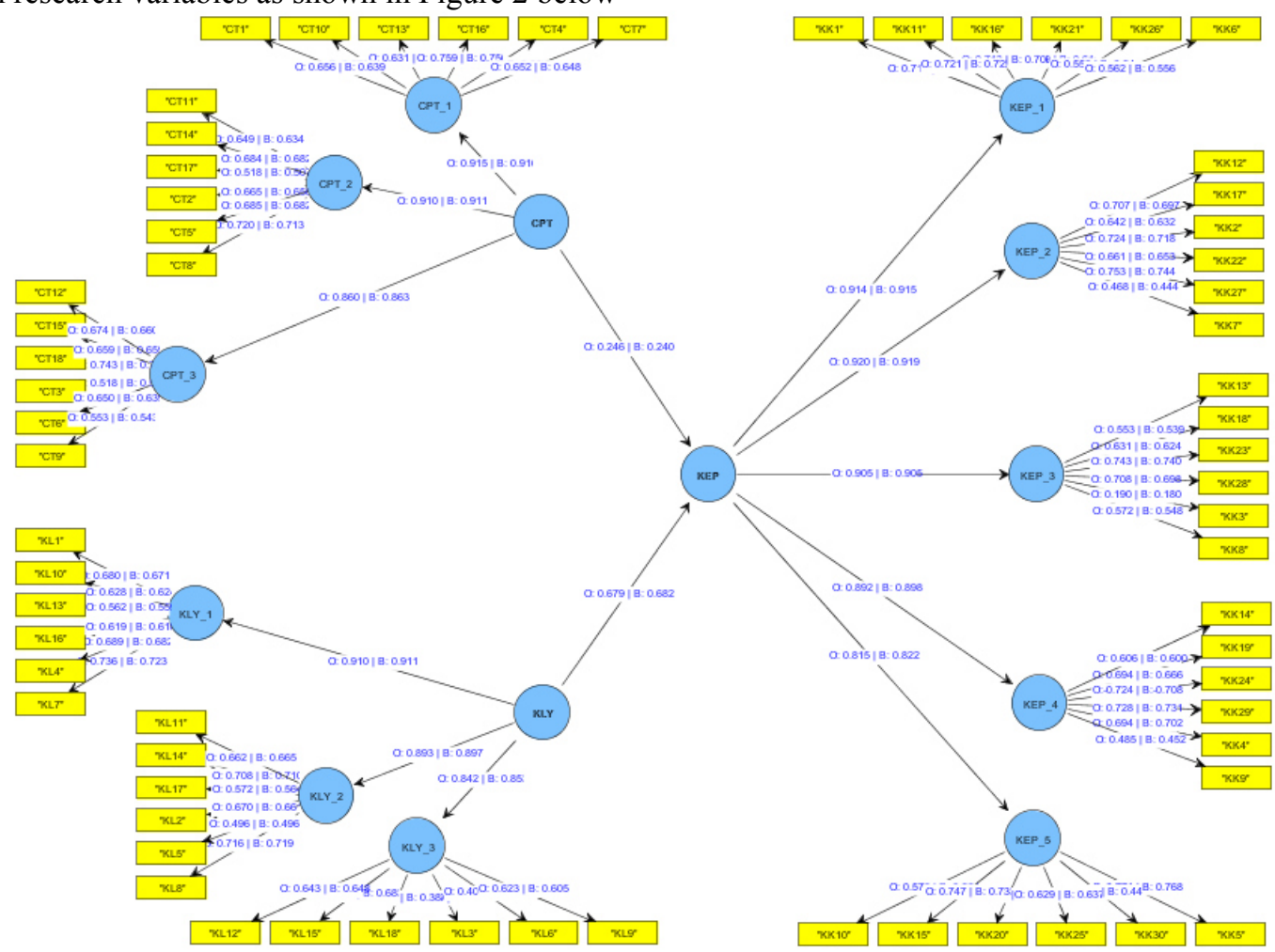

Figure 2

The Effect of Higher Education Image (CPT), Service Quality (KLY) on Student Satisfaction (KEP) with Bootstrap Sample

From Figure 2, it can be explained that the image of higher education has a direct effect on consumer satisfaction of 0.246 , while service quality has a direct effect on consumer satisfaction of 0.679 .

While the contribution of Higher Education Image and Service Quality to Consumer Satisfaction is 0.780 and answers hypothesis 3 . The results of this study are in accordance with Adam's (2015) opinion that one of the factors that influence consumer satisfaction is image. The results of this study also prove the theory of Lupiyoadi (2006) which argues that service quality is one of the factors that influence customer satisfaction. According to Wood (in Lupiyoadi, 2006) the specific benefits of customer satisfaction for companies include a positive impact on customer loyalty. Service quality will be a measure of a consumer's satisfaction so it is an important thing to pay attention because it will affect consumer behavior in the short or long term. Customer satisfaction refers to certain times when a service is provided or from the beginning to the end of a service being provided. Service satisfaction can be seen directly from how much consumers like or not the services they get. Overall service satisfaction is indicated by whether or not consumers are satisfied with the overall services provided by a service agency. Service quality standards must be applied in order to achieve the expected goals. In addition, the company is also required to make the consumers happy not only to satisfy customers by providing appropriate services and added value for customers.

In the context of higher education, student satisfaction while studying at University "X" has a positive impact with good perceptions. This could be a potential recurrence of continuing higher level of education at University "X" (post graduate) or recommending others to study at University "X" (positive word of mouth)

The hypothesis which states that the image of higher education has an effect on consumer satisfaction is proven. This can be seen from the path coefficient with a positive sign of 0.246 with a t-statistic of 1.993 which is greater than $\mathrm{t}$ table $=1.96$. This shows that the image of the university has a significant effect on consumer satisfaction of 0.246 . Campus image has a positive influence on student satisfaction. The image of the university is one of the factors that can satisfy students both in terms of morality, management, performance and services provided by universities to students and other customers. The results of previous research, conducted by Cid, Renata and Alexander, 2004 (in Panjaitan, 2011) found one of the results of their research that image had a direct effect on satisfaction. Dib (2013) also found one finding of his research that image has a direct influence on student satisfaction at Syrian Universities. Meanwhile, research by Arwanda et al (2014) and research by Setiyawan (2016) showed the same result that the image of the university has an effect on student satisfaction. Likewise, the results 
of Mujahidin's research (2018) that the image of universities has a positive influence on student satisfaction of IKIP PGRI Bojonegoro.

The hypothesis which states that Service Quality has an effect on Consumer Satisfaction is proven. This can be seen from the path coefficient with a positive sign of 0.679 with a t-statistic of 6298 which is greater than t table $=1.96$. This shows that service quality has a significant effect on customer satisfaction of 0.679 . The relationship between service quality and customer satisfaction is strong. Service quality is a powerful weapon in the competitive advantage of a company, including in higher education. So with the quality of service that is implemented properly it will create consumer satisfaction. If consumers are not satisfied, it can have a negative impact on customer loyalty, eliminate potential future sources of income, reduce bargaining power of stakeholder.

This is provent from the results of previous studies. The results of research conducted by Rustami et al (2000) based on testing the coefficient of determination obtained the results of $52.5 \%$. This illustrates that student satisfaction is influenced by the quality of educational services by $52.5 \%$ while the remaining $47.5 \%$ is influenced by other variables such as image, perceived value, costs felt by students and others which unresearched. Jeanne Ananti Susanto, 2004 (in Panjaitan, 2011) examined the effect of service quality and perceived value on the satisfaction of 140 consumers in Surabaya. The statistical test used was the AMOS program SEM and it was found that one of the results of the study was that service quality significantly affected customer satisfaction. The findings in Indrawati's research (2011) conclude that partially and simultaneously the dimensions of service quality (reliability, direct evidence, responsiveness, assurance and empathy) provided by the Arithmetic Mental Education Institute in Malang City have a positive and significant effect. Likewise research conducted by Reina (2012), the results show that service quality has a significant effect on student satisfaction. The conclusion from Rinala's research (2013) showed that the quality of academic services can be explained by five factors, namely physical evidence, reliability, responsiveness, empathy and assurance, has a weak effect on STP Nusa Dua Bali students. Structural analysis of the model using multiple regression analysis, gives the result that the quality of academic services has a positive and significant effect on student satisfaction, namely $89.5 \%$.

\section{Conclusion}

The results of the study resulted in the following findings. First, there is the effect of Campus Image and Service Quality on Consumer Satisfaction of 0.780. Second, the image of Campus has a significant effect on consumer satisfaction of 0.246 . Third, service quality has a significant effect on consumer satisfaction of 0.679 .

Suggestions that can be given are as follows: First, for educational institutions, namely University " $X$ ", it can be a recommendation for rules or policies related to student satisfaction. Second, for future researchers, it can be the basis for universal and theoretical discourse on consumer satisfaction models. In addition, it contributes to the application of theory in the field of industrial and organizational psychology, especially consumer behavion.

\section{References}

Adam, M (2015). Manajemen Pemasaran Jasa Teori dan Aplikasi. Bandung: Alfabeta.

Arwanda, Hartoyo \& Sri. (2014). Kepuasan, Citra dan Loyalitas pada Lembaga Pendidikan Tinggi: kasus di Akademi XYZ

Dib, H., Mokhles Alnazer, M. (2013) ConcePTual Model Of Student Satisfaction In Syrian Universities. European Journal Of Economics, Finance And Administrative Sciences. Januari

Dirgantari, P. D. (2012). Pengaruh Kualitas Layanan Jasa Pendidikan Terhadap Kepuasan Mahasiswa serta Dampaknya Terhadap Upaya Peningkatan Citra Perguruan Tinggi Negeri Menuju World Class University (Studi pada Mahasiswa Asing di ITB, UNPAD, dan UPI). Jurnal ilmu manajemen dan bisnis, 3(2).

Indrawati, A. (2011). Pengaruh Kualitas Layanan Lembaga Pendidikan terhadap Kepuasan Konsumen. Jurnal Ekonomi Bisnis, Th. 16, No. 1

Lupiyoadi, \& Hamdani. (2008). Manajemen Pemasaran Jasa. Edisi 2. Salemba Empat.

Lupiyoadi, R. (2006). Manajemen Pemasaran Jasa Edisi Revisi. Salemba Empat. Jakarta

Mujahidin, A., Zuhriah, F., Khoirianingrum, I., (2018) Pengaruh Citra Perguruan Tinggi dan Kompetensi Dosen terhadap Loyalitas Mahasiswa melalui Kepuasan Mahasiswa Pada Perguruan Tinggi Swasta (Studi pada IKIP PGRI Bojonegoro). Al Tijarah: Vol. 4 No. 2, Desember 2018 (49-66)

Panjaitan, H (2011) Ssitem Informasi, Kualitas Layanan, Citra, dan Respon Konsumen Perguruan Tinggi. Surabaya : Revka Petra Medika

Rustami, NA., Nuraedi, Kurniatun, TC ( ) Pengaruh Kualitas Jasa Pendidikan Terhadap Kepuasan Mahasiswa Di Universitas Pendidkan Indonesia. Jurnal Adpend 42

Reina (2012) Faktor-Faktor Yang Mempengaruhi Kepuasan Mahasiswa Pada Universitas Bina Nusantara. Binus Business Review Vol. 3 No. 1

Rinala, N., Yudana, I.M., Natajaya, I.N. (2013) Pengaruh Kualitas Pelayanan Akademik Terhadap Kepuasan Dan Loyalitas Mahasiswa Pada Sekolah Tinggi Pariwisata Nusa Dua Bali., e-Journal Program Pascasarjana Universitas Pendidikan Ganesha Program Studi Administrasi Pendidikan (Volume 4) 
Setiyawan. (2016). Membangun citra kampus melalui kepuasan mahasiswa berdasarkan kualitas layanan. Arthavidya, Vol. 18 No. 2

Tjiptono, F \& Chandra, G. (2016). Pemasaran Jasa (Prinsip, Penerapan, dan Penelitian), Yogyakarta: Andi Universitas Hang Tuah. (2019) . Laporan Program Kerja Universitas Hang Tuah Tahun Akademik /2020

Zeitharml, V. A. 1990. Delivering Service Quality: Balancing Customer Perceptions and Expectations. New York: The Free Press. 